\title{
PARA VIRAR AL MACHO: LA AUTOBIOGRAFÍA COMO SUBVERSIÓN EN LA CUENTÍSTICA DE MANUEL RAMOS OTERO
}

\author{
POR
}

\author{
ARNALDO CRUZ-MALAVÉ \\ Fordham University
}
Manuel R. O. - Organizar actividades culturales me quita todo el tiempo.
Ronald M.-C. -Pero así estás haciendo patria.
Manuel R. O. - La patria soy yo.
Arnaldo C.-M. -También se hace patria con la pluma.
Manuel R. O. - Con las plumas. ${ }^{1}$

A Manuel, recordándolo.

Desde su primer libro de cuentos, Concierto de metal para un recuerdo y otras orgías de soledad, hasta su texto más reciente, Cuentos de buena tinta ${ }^{2}$ Manuel Ramos Otero cultivó siempre algo que podría calificarse de insólito en la narrativa puertorriqueña: la abierta, franca y descarada indagación del yo, del yo que escribe. Como afirmó él en varias ocasiones y como reiteró en una de sus últimas conferencias, su escritura no era sino el relato de su biografía, su autobiografía: "Yo siempre he sido el protagonista de mi obra".3 Sus cuentos parecen confirmar esta intención autobiográfica, este narcisismo de la escritura, en varios niveles. Gran parte de sus personajes reproducen hechos de su vida.

\footnotetext{
${ }^{1}$ Extraído de una conversación del autor del ensayo con Manuel Ramos Otero y Ronald Méndez-Clark.

${ }^{2}$ Ramos Otero (1948-1990) publicó en vida tres libros de cuentos: Concierto de metal para un recuerdo y otras orgías de soledad (San Juan: Cultural, 1971), El cuento de la Mujer del Mar (Río Piedras: Huracán, 1979), Página en blancoy stacatto (Madrid: Playor, 1987); una novela, La novelabingo (Nueva York: El Libro Viaje, 1976); y un libro de poesía, El libro de la muerte (Río Piedras/Nueva York: Cultural y Waterfront Press, 1985). Postumamente ha aparecido su poemario, Invitación al polvo (Río Piedras: Plaza Mayor, 1991) y una colección de cuentos que incluye Concierto ..., El cuento ... y cuentos dispersos, publicados en revistas: Cuentos de buena tinta (San Juan: Instituto de Cultura Puertorriqueña, 1992).

3 "Ficción e historia: texto y pretexto de la autobiografía", "Primer Congreso de Escritores y Poetas Puertorriqueños en Nueva York", 19 de noviembre de 1988, 6. Copia del autor.
} 
Personajes como Clara Gardenia Otero y el cuentero Ramos, en el "Romance de Clara Gardenia Otero" e "Inventario mitológico del cuento", llevan respectivamente su apellido. Los personajes de Ramos Otero también duplican con frecuencia sus circunstancias: son exiliados o escritores o ambos. En "EI cuento de la Mujer del Mar", la protagonista no sólo es una escritora puertorriqueña exiliada en Nueva York sino que es además original de Manatí, pueblo de la costa de Puerto Rico donde nació Ramos Otero. Quizás el relato que mejor confirma la intención autobiográfica de este escritor sea el que cierra su libro Página en blanco y stacatto, "Descuento". En éste, Ramos Otero pretende explicar o, mejor, "justificar" todos los cuentos que preceden remitiéndolos a su biografía. Aún en relatos como "El cuento de la Mujer del Mar" en los que el autor se propone escribir la biografía fabulada de otro personaje (concretamente, la de Julia de Burgos), esta biografía termina, en últimainstancia, confundiéndose con la del escritor. Estamos pues frente a un escritor para quien los personajes son, como sucede con Pessoa; Vallejoy Borges, personae, máscaras que se asumen para la investigación del yo, del yo que escribe.

Precisamente, al igual que en estos escritores, la indagación del yo en Ramos Otero no es simplemente una forma de expresar, de revelar, como pretendían los románticos, un yo verdadero. Más cercana a Pessoa, su intención sería constatar la ficticidad del yo y el dialogismo radical que lo constituye, comprobar esa dialéctica entre lo que Pessoa llamaba el "Eu profundo e os otros Eus". Como ha explicado el autor, detrás del yo, del yo que cuenta, en su doble acepción de narrador y de voz autorizada, está la multiplicidad de voces que lo conforma, multiplicidad de voces que el concepto realista del término intenta contener, reprimir, borrar:" "Si, el acento se pone sobre la vida individual, pero el acento siempre ha estado puesto, gramaticalmente sobre el Yo que también es $T u ̈$ que además es $E l$ que siempre es Ella ..." "Ficción e historia ...", 8). Más que una revelación de un yo profundo, más que el descubrimiento de una identidad pospuesta, la investigación del yo en Ramos Otero es, como en Cortázar, modelo reiterado de su cuentos, una meditación sobre la autoridad, la autoria.

Así como "Las babas del diablo" de Cortázar cuestiona la autoridad del yo que escribe desplazando constantemente el punto de vista de la narración del escritor convertido en personaje a su doble, el protagonista Roberto Michel, de éste a su cámara fotográfica ("... nadie sabe bien quién es el que verdaderamente está contando, si soy yo o eso que ha ocurrido ...", explica el narrador ${ }^{5}$; en los

\footnotetext{
${ }^{4}$ Para una lectura complementaria a la mía, centrada en el dialogismo de la escritura de Ramos Otero, cf. Juan Gelpí, "Entre el exilio y la reunión de voces: Página en blanco y staccato de Manuel Ramos Otero". Copia del autor.

- Ceremonias [contiene Final del juego y Las armas secretas] (Barcelona: Seix Barral, 1970), 202. En adelante citamos de las obras de Cortázar por Ceremonias, Todos los fuegos el fuego (Buenos Aires: Sudamericana, 1986), Rayuela (Buenos Aires: Sudamericana, 1975), Pameos y Meopas (Barcelona: Ocnos, 1971).
} 
cuentos de Ramos Otero, el yo que cuenta, lo que él llama "el cuentero", se desdobla en protagonista, pasa sin transición de yo a él o, destacando su función de máscara, de simulador, de travestí, ${ }^{6}$ se desplaza con mayor frecuencia de yo a ella. De igual manera, el protagonista concebido como el "otro", como el lector, espectador o receptor de la narración, como el objeto de amor deseado, amado y asesinado, puede, a su vez, convertirse en el escritor-amante-asesino. Como los relatos de Cortázar, los cuentos de Ramos Otero no representan un argumento, en el sentido realista del término, sino una serie de relaciones fundamentales de la escritura, de tensiones entre términos que se definen diferencialmente, que son, a cada momento, susceptibles de mutarse en sus contrarios, en sus otros.

\section{"Detrás de todo cuento ... hay un cadáver perfumado"}

Una de éstas es la relación entre el escritor y el lector o receptor de la narración. A contrapelo de lo que Luis Rafael Sánchez ha llamado las "palabras divinas" de René Marqués ${ }^{7}$ o del yo colectivo que se apropia la voz de "El hombre en la calle” de José Luis González; Ramos Otero, Sánchez y la promoción de escritores puertorriqueños posteriores al 70, instauran en la literatura nacional la rebelión del lector contra la voz unitaria, autoritaria y patriarcal del yo que escribe, la llamada "muerte del autor" tan anticipada por Mallarmé y tan preconizada por los estructuralistas. Es ésta, para usar una expresión de Emir Rodríguez Monegal con respecto a una generación argentina, una generación parricida, primitiva horda freudiana que incita a la muerte del padre y el autoritarismo. En la obra de Ramos Otero, esta intención parricida se confirma en la presencia constante del cuerpo, del cadáver que no desaparece o que se descompone, como en Poe, ante los ojos del lector. Su obra se sitúa en esta zona del asesinato;representa la reproducción incesante, la dramatización obsesionada de una escena primaria en la cual se desconstruye, se desdibuja, la voz unitaria del padre y el yo autoritativo de la generación puertorriqueña del 50.8 En ella, todas las estrategias narrativas se despliegan conscientemente para la realización de unos ritos fúnebres. "Detrás de todo cuento ... hay un cadáver perfumado", explica el narrador de "Inventario mitológico del cuento" (El cuento ..., 79). A diferencia de la obra de Puig que intenta postular, según el análisis de Elías

\footnotetext{
${ }^{6}$ Sobre la escritura como simulación, travestismo, véase Severo Sarduy, La simulación (Caracas: Monte Avila, 1982).

7 "Las divinas palabras de René Marqués", Sin Nombre X, 3 (octubre-diciembre 1979): 11-14.

${ }^{8}$ Esta generacion, a la que pertenecen René Marqués, José Luis González, Pedro Juan Soto, Emilio Díaz Valcárcel y César Andreu Iglesias, es conocida también como la generación del 40 y la generación de la Segunda Guerra Mundial. Ver José Luis González, "Un testimonio puertorriqueño" en Imágenes e identidades: el puertorriqueño en la literatura, edición de Asela Rodríguez de Laguna (Río Piedras: Huracán, 1985) 17-22.
} 
Miguel Muñoz,9 una utopía antipatriarcal bisexual, o a diferencia aún de lo que Sarduy ha llamado despectivamente el "arte oficialmente gay ${ }^{10}$ que pretende desplazar el centro ocupado por el padre para situar en él una ontología homosexual, una esenciagay; la obra de Ramos Otero marca un impasse, remite incesantemente a la dialéctica entre la generación antecesora y su generación, entre el yo unitario patriarcal y el dialogismo desconstructor, sexualmente polimorfo. Si bien su escritura convoca insistentemente al autor-padre; sus estrategias narrativas lo invierten y lo desplazan ${ }^{11}$ hacia esa escritura plural, heterogénea que Hélène Cixous ha llamado "bisexual", donde las diferencias, lejos de ser "anuladas", son "promovidas", "perseguidas", "aumentadas". ${ }^{12}$

En los relatos de lo que Doris Sommer ha llamado las etapas surrealista y existencial de Cortázar, etapas que comprenden desde Bestiario y Final del juego hasta Todos los fuegos el fuego y Octaedro, ${ }^{13}$ la rebelión del lector contra el autor, su muerte, su asesinato, se presenta como el paso de la receptividad femenina a la actividad masculina, de la pasividad a la creatividad fálica. En "Las Ménades", por ejemplo, los receptores de la obra, o lo que el texto identifica como "la enorme hembra de la sala entregada" (Ceremonias, 52), se transforman en agentes activos al agredir a sus productores o ejecutores, o lo que el cuento califica de "el cuerpo masculino de la orquesta" (52), convirtiendo así la obra, a la fuerza, en una verdadera opera aperta. Si bien la rebelión del lector, en los relatos de estas dos etapas cortazarianas, constituye, frente al conceptopatriarcal, unitario del autor, una apertura y una liberación; ésta se fundamenta también en una subordinación: en la afirmación de un concepto genérico tradicional en el cual, como explican Sandra Gilbert y Susan Gubar en The Madwoman in the Attic, el proceso de la escritura se concibe como la incisión de la pluma-falo en la página-vagina, comola actividad creadora del verbo fálico, ${ }^{14}$ conceptogenérico tradicional consagrado por Cortázar, en Rayuela, en la ya famosa fórmula de los

- El discurso utbpico de la sexasalidad en Manuel Puig (Madrid: Editorial Pliegos, 1987).

${ }^{10}$ En La simulación Sarduy critica el "arte oficialmente gay " que, por gu "fascinación helénica [,] coincide con el más edulcorado realismo académico" (p. 118), y opone a este arte gay, y al realismo en general, el arte de la "simulación", de la exposición del cuerpo, de la materia misma de la obra artística, de sus soportes, sus significantes.

11 "Explanation and Culture: Marginalia", In Other Worlds: Essays in Cultural Politics [Nueva York, Londres, Routledge, 1988], donde Gayatri Chakravorty Spivak describe lo que ella llama la práctica desconstructiva de reversal-displacement, 103-117.

${ }^{18}$ The Newly Born Woman, traduccion de Betsy Wing, introduccion de Sandra M. Gilbert (Minneapolis, University of Minnesota Press, 1986), 86.

13 "ANowhere for Us: The Promising Pronouns in Cortáar's 'Utopian'Stories", Dispositio IX, 24-26 (1984), 65-90.

14 En particular "The Queen's Looking Glass: Female Creativity, Male Creativity, Male Images of Women, and the Metaphor of Literary Paternity", The Madwoman in the Attic: The Woman Writer and the Nineteenth-Century Literary Imagination (New Haven: Yale University Press, 1979) 3-44. 
"lectores hembra" y los "lectores cómplices" (o por implicación, "machos"). En tanto que esta distinción entre la receptividad femenina y la actividad creadora masculina que fundamenta la rebelión del lector cortazariano, permanece, por lo menos para los personajes de estos cuentos, latente, los personajes de Ramos Otero la asumen conscientemente y la convocan. Como ha explicado Sommer, los personajes de Cortázar parecen ser sorprendidos e incididos, en su etapa surrealista, por una superrealidad o irrealidad que no llegan a comprender plenamente pero a la que se ven obligados a acatar, o se desplazan, en su etapa existencialista, hacia una serie de juegos verbales, patrones lingüísticos, planos textuales o trampas, cuyas reglas, desconocidas por ellos, los llevan inevitablemente a su pérdida o muerte $(66,71-78)$. Los personajes de Ramos Otero, por el contrario, conjuran conscientemente su descentramiento; loexigen a voces; lo provocan. En una estrategia que podríamos calificar de perversa, en sentido estricto, sus personajes, el narrador incluso, se proponen rebelarse no sólo contra el yo unitario del autor sino también contra la distinción que fundamenta esa rebelión en Cortázar recurriendo al tópico, activa y conscientemente asumiendola posición pasiva, subalterna de "lectores hembra". Como Genet, quien abogaba a favor de la estrategia más accesible al marginado: la asunción de la marginación, del insulto, ${ }^{15}$ los personajes de Ramos Otero asumen la pasividad conscientemente y organizan la ceremonia y el juego, disponen las tácticas narrativas que conciten el yo unitario, el verbo fálico del autor para luego virarlo, asesinarlo.

\section{Los cuerpos de la marginación}

En "Inventario mitológico del cuento" - relato que, como sugiere el título, es una especie de enumeración, no suma o totalización orgánica, de los recursos y relaciones fundamentales de la cuentística de Ramos Otero- todos los personajes, incluso el narrador, el cuentero Ramos, son lectores de Cortázar. Todos estos personajes - una "cocinera de leyenda, una poetisa laureada, una emperatriz andrógina" (El cuento ..., 75), y el cuentero- asumen literalmente la posición de "lectores hembra", e invocan, por medio de su lectura, el verbo fálico del autor Cortázar. Más que personajes redondeados, poseedores de una psicología profunda, los personajes "femeninos" de "Inventario ..." -la cocinera Carmen Cachete, la poetisa Ola Sola y la emperatriz china- son caricaturas; más que mujeres, representan algunas de las posiciones genéricas obtenibles en la sociedad puertorriqueña. Sus nombres, con su carácter espectacular, de estrellas de la farándula o travestís famosos, destacan su función de signos o nodos semánticos en los cuales converge una serie de posiciones y prácticas subordinadas, consideradas "femeninas" en la sociedad boricua. Las posiciones

\footnotetext{
${ }^{28}$ Para un análisis de Genet desde esta perspectiva, ver Stephen Adams, The Homosexual As Hero in Contemporary Fiction (Londres: Vision Press Limited, 1980) 182-205.
} 
y prácticas que sus nombres designan podrían describirse como las de la mujer como guardiana del hogar y de la autoctonia, como voz de lo bello y emotivo y como espiritista, nigromante o adivina.

En el personaje de Carmen Cachete se conjugan algunas de las representaciones de lo femenino que se identifican, en la cultura puertorriqueña, con lo nacional. Maestra de la cocina criolla, experta en yerbas medicinales, conocedora de remedios y brebajes para contrarrestar traumas psicológicos, desamores y maleficios, Carmen Cachete, como el personaje de La guaracha del Macho Camacho, de Luis Rafael Sánchez, Doña Chon, es un personaje de larga tradición en la literatura puertorriqueña, cuya tipicidad los escritores contemporáneos han comenzado a parodiar. Como revelan estas parodias, su monumentalización, su elevación a símbolo de lo autóctono y nacional, se fundamenta en una serie de reducciones: se erige sobre la reducción de la patria al hogar, de éste a la mujer y de ésta al grado cero de su existencia: su función de sostén material y espiritual de la familia. Reificada, obligada a representar las tradiciones criollas, el saber popular, a ser sólo índice u objeto, Carmen Cachete se desmiembra en citas

(Carmen Cachete aconseja: cataplasmas de mostaza para el que te dé calabaza, de jengibre y yerbabuena para el te pone nueva, un pase de Agua Florida en la ida y la venida, del café guarda la borra si es que te sale machorra, si su cigarrillo es Campeche échele un puño de leche.) (El cuento ..., 76)

Voz de lo bello y emotivo, la poet(is)a Ola Sola encarna el concepto crítico tradicional que define la escritura femenina como una expresión de la intimidad. Es ella un emblema de lo que Aurea María Sotomayor, en un estudio antológico, ${ }^{16}$ ha denunciado como la relegación de la poeta latinoamericana al terreno de lo afectivo y personal, comoel encasillamiento de un género en un género: la lírica. Conforme a este concepto tradicional, la poeta no elabora una obra sino que se expresa al revelar una naturaleza femenina, previamente constituida. Como el sufijo que la naturaliza, la configura en ente poético, la objetiva: "isa", la poet(is)a no necesita, como el poeta, dominar el entorno para crear, sino manifestar, en una suerte de arrebato extático, el estado poético que es. No sorprende por tanto que las otras dos representaciones de Ola Sola en "Inventario ...” la conviertan de sujeto en objeto, de agente en paciente de la poesía. Además de poet(is)a, Ola Sola personifica la página en blanco, página virgen sobre la cual ha de incidir la pluma fálica del poeta ("en el caney de la emperatriz, Ola Sola esperaba con las piernas abiertas de su poesía la llegada del Conde Carlos (lo vas a reconocer por el bicho de piedra)" [El cuento ..., 76]); así como la tradición poética misma, musa-madre que espera, según el modelo de la "ansiedad de la

${ }^{16}$ De lengua, razón y cuerpo (Nueve poetas contemporáneas puertorriqueñas) (San Juan, Instituto de Cultura Puertorriqueña, 1987). Antología y ensayo crítico. 
influencia" de Harold Bloom, ${ }^{17}$ la actualización que el poeta hombre hará de ella en su intento por poseerla. Medio de lo bello y emotivo, página en blanco o musamadre, la poet(is)a sublime Ola Sola, como signo plurivalente o nodo semántico, recoge algunas de las posiciones de subordinación accesibles a la escritora puertorriqueña.

En la emperatriz china convergen algunas de las formas de conocimiento intuitivas y esotéricas, marginadas en la sociedad puertorriqueña: el espiritismo, la magia populary los llamados cuentos de abuelas, así comocierto confucianismo kitsch que el narrador de "Inventario ..." califica de "cuentos de abuela mongólica" (72) y formas hibridas o sincréticas como el "Tarot taíno" inventado o encontrado por la emperatriz china. Al igual que la Jesusa de Hasta no verte Jesús mío (1969) de Elena Poniatowska y algunas mujeres coloniales mexicanas estudiadas por Jean Franco, ${ }^{18}$ la emperatriz china recurre a estos códigos para acceder al poder (fálico). Pero, a diferencia de éstas y en conformidad con uno de los procedimientos fundamentales de la narrativa de Sarduy analizados por Roberto González Echevarría, ${ }^{19}$ la emperatriz china no recurre a ellos como sistemas totalizadores, generadores de significados alternos, de verdades hasta entonces silenciadas o excluidas, sino como sistemas desarticulables cuyos fragmentos, desplazados de sus antiguos centros de significación y autenticidad, pueden ser recombinados como meros significantes en formas diversas e inusitadas y para crear efectos específicos y provisionales. No se trata en su caso, como en el de Jesusa, de la afirmación de creencias marginadas que dotan al sujeto de una nueva identidad contestataria sino de la rearticulación de fragmentos de códigos intuitivos y esotéricos en un mundo donde la verdad ha desaparecido y no es pertinente. Como travestí, la emperatriz china asume estos códigos como simples máscaras, como otros simulacros más.

Si bien estos personajes "femeninos" —Carmen Cachete, Ola Sola y la emperatriz china - designan posiciones genéricas subordinadas y prácticas culturales subalternas en la sociedad puertorriqueña, hay un personaje en "Inventario ..." que representa el territorio, la zona misma donde se inscriben estas posiciones y prácticas: la Corteja de la Vida. Muerta de cáncer en los senos, la Corteja de la Vida se identifica, desde un principio, con la Isla de Puerto Rico. Su cuerpo reducido, por sinécdoque, a sus tetas de silicona se identifica con la Isla, reducida también, por sinécdoque, a las montañas de la Cordillera

${ }^{17}$ The Anxiety of Influence: A Theory of Poetry (New York: Oxford University Press, 1973). ${ }^{18}$ Plotting Women: Gender and Representation in Mexico (Nueva York: Columbia University Press, 1989). Cf. en particular el capitulo, "The Power of the Spider Woman: The Deluded Woman and the Inquisition" ${ }^{n}$ 55-76.

${ }^{19}$ En La ruta de Severo Sarduy (Hanover, Ediciones del Norte, 1987) González Echevarria describe el procedimiento de la demolición de sistemas totalizadores y su recombinación fragmentaria y estratégica en base a juegos de significantes, que caracteriza la narrativa sarduyana, 67-68. 
Central popularmente conocidas como las Tetas de Cayey. Todo "Inventario ..." podría describirse como la preparación de los ritos fúnebres de la Corteja de la Vida, y su cuerpo, que atraviesa las páginas del cuento, como el espacio mismo donde concurren los personajes, sus "amigos, la cara múltiple del enterrador" (75). Combinando elementos de una sesión espiritista, una comunión, un sacrificio y una violación, esta ceremonia final convoca a los personajes al desmembramiento, tajamiento, tatuaje e ingestión del cuerpo de la Corteja de la Vida. Al igual que la comunión cristiana, ésta los invita a la cena-sacrificio que los constituirá, como cómplices, en una nueva comunidad, un nuevo cuerpo simbólico —el del cuento:

La cena está servida, dijo Carmen Cachete arrodillada a la japonesa, y siguío peinando la cabeza colorada de la Corteja de la Vida, la cena está servida repitió la emperatriz china ... la cena ésta servida, dijo el [narrador] asesino tatuando los mapas epidérmicos de la Corteja de la Vida con los relatos de la Quinta Edicion"(85).

La Corteja de la Vida no sólo es el territorio, la es(cena) en que concurren los personajes, sino también el cadáver que presupone el cuento: el cuerpo que hay que tajar, tachar, tatuar para constituir el relato. Es el cuerpo ausente pero presente (presente por ausente), borrándose, borrado bajo la escritura de la pluma-falo, la pluma-escal pelo: "la cena está servida, dijo el [narrador] asesino tatuando los mapas epidérmicos de la Corteja de la Vida con los relatos de la Quinta Edición”. El cuerpo tachado, sous rature, de la Corteja de la Vida es, por un lado, la huella (trace) del origen siempre inaccesible, siempre a distancia, que presupone, según Derrida, toda escritura. ${ }^{20}$ Pero es además el cuerpo femenino que, según Cixous, la lógica binaria, jerárquica de la ideología patriarcal intenta incor porar como término pasivo o concibe como cuerpo muerto. ${ }^{21}$ Es la huella de lo excluido: la otredad radical que, conforme a Luce Irigaray, el razonamiento especular patriarcal pretende obviar al asimilar el cuerpo femenino a un cuerpo masculino castrado, a una copia defectuosa. ${ }^{22}$ El cuerpo "femenino" de la Corteja de la Vida funciona pues, en todos estos casos, como la marca legible de una ausencia determinada, imprescindible; la "palabra hueca" (parole creuse) que postula Macherey, sobre la cual se erige y elabora el sistema de oposiciones ideológicas ${ }^{23}$. Apunta, por un lado, al polimorfo cuerpo materno del estadio

\footnotetext{
${ }^{20}$ Sobre el concepto derrideano de sous rature, v. Gayatri Chakravorty Spivak, prefacio a su traducción de De la grammatologie (OfGrammatology [Baltimore: The Johns Hopkins University Press, 1977]), xxxix.

21 Véase "Sorties", The Newly Born Woman, 64-65.

22 En particular "La Petite fille (n') est (qu') un petit garçon" (25-36) y "Toute théorie du 'sujet' aura toujours été appropriée au "masculin" (165-182), Spéculum de l'autref emme (Paris: Minuit, 1974).

${ }^{23}$ En particular el capitulo "Explication et interprétation" de Pour une théorie de la production litteraire (Paris: François Maspero, 1966), 97-98.
} 
lacaniano de "lo imaginario", voz que "insufla", según Cixous, la escritura "femenina" (92-93), y es, por otro, el índice, la señal, el tajo que marca la exclusión, la supresión de este cuerpo efectuada por la ideología patriarcal, falocéntrica.

\section{El fetiche de la escritura}

A diferencia de Cixous, "Inventario ..." no propone una relación inmediata entre la escritura y el cuerpo materno. En Ramos Otero el cuerpo femenino sigue siendo lo inexpresable; lo que, al referirse a los límites del sistema de oposiciones jerárquicas, Cixous ha llamado "To impensable, el impensamiento" (64-65). Es por ello que incluso las prácticas culturales de los personajes "femeninos", marginados de "Inventario ..." no emanan, como sucede con la escritura "femenina" de Cixous, de una voz materna previa a las oposiciones jerárquicas, sinoque están ya, desde siempre, inscritas en la economía patriarcal, binaria de lo ideológico. Son prácticas que, como dijimos, asumen el estereotipo e instituyen, desde él, su crítica, su resistencia. Sobre el cuerpo asesinado de la Corteja de la Vida se erigen pues todas las posiciones subjetivas y prácticas culturales de "Inventario ...", incluso las marginadas de Carmen Cachete y la emperatriz china. Así que Carmen Cachete, cocinera criolla, guardiana del hogar boricua, haga gala de los conocimientos culinarios que la definen en la preparación del cuerpo de la Corteja de laVida para la es(cena)final: condimenta su cuerpo con la sazón nativa:

y vio cuando Carmen Cachete, fosas nasales rellenas, se precipitaba sobre la muerta con las botellitas de especies: ¡más polvo de canela sobre la boca! jéchale nuez moscada ahora hazle una corona de clavos échale orégano en la chocha comino y pimienta en el ombligo vírala bocabajo y sazónale las nalgas con hojas de laurel sóbala con aceite de oliva y aderézale los poros con ajo machacado (78)!

Al preparar el cuerpo de la Corteja de la Vida, Carmen Cachete lo adereza por partes, lo corta, lo desmiembra, nivelando sus zonas erógenas - en orden de presentación: la oral (la boca), la genital (la chocha) y la anal (las nalgas)-e instalando sobre él, como fetiche, la práctica culinaria que es ella. De igual manera, la emperatriz china, espiritista y adivina, prepara el cuerpo de la Corteja de la Vida para la práctica erótico-religiosa que la denomina: la tortura corporal: "la reputación la cogí en Shanghai, donde tajeaban tetas las sociedades secretas" (80). Y coloca sobre él, como maquillaje y fetiche, el tajo de la navaja, su inscripción: "la cena está servida, repitió la emperatriz china arrodillada al extremo opuesto de la mesa pintándole las uñas de los pies a la Corteja" (85).

Tanto las prácticas subalternas de los personajes "femeninos" como las dominantes de los "masculinos" - el cuentero Ramos, el Conde Carlos y el autor Cortázar- se instalan sobre el cuerpo asesinado de la Corteja de la Vida. 
Conforme a la metáfora sarduyana que concibe la escritura como tatuaje, ${ }^{24} \mathrm{el}$ cuentero-asesino tacha el cuerpo materno de la Corteja de la Vida, y escribe sobre él su nueva lectura, su reescritura de la tradición literaria, de las obras del autor Cortázar: "la cena está servida, dijo el asesino [el cuentero Ramos] tatuando los mapas epidérmicos de la Corteja de la Vida con los relatos de la Quinta Edición" (85). Paralelamente a este tatuaje, el Conde Carlos, "como una baraja [del Tarot taíno], mano en bicho [pene] de piedra" (84), en "fungiforme Yocahú, ${ }^{25}$ monta el "caballo amarillo", que en el relato cortazariano "El perseguidor" representa al artista ${ }^{26}$ para penetrar-asesinar a la poet(is)a-poesía Ola Sola. Parodiando el famoso verso antimodernista de González Martínez, el clímax literal de "Inventario ..." ocurre con esta penetración-asesinato de Ola Sola por parte del Conde Carlos, de la poesía por el verbo fálico del autor:

Agarró la poesía por el cuello blanco de cisne de mármol y la ahorcó, chichó la cara de la poesía, mamó las tetas rosadas de la poesía hasta dejarlas como ciruelas, metió los dedos en la doncellez de armiño de la poesía y la descubrió mojada y resbaladiza como un loto carnívoro, le rompí la telita divina a la poesía y fue reconociendo las vueltas y callejones inesperados, preño la poesía de ladito dejándola medio marginada en un camino polvoriento por el que siguió galopando su caballo de oro derretido (84-85).

Así como el cuentero Ramos tatúa el cuerpo de la Corteja de la Vida, el Conde Carlos desmiembra el cuerpo de Ola Sola e instala sobre él la clave del Tarot taíno encontrado o inventado por la emperatriz china, la nueva escritura: "Semen-té-río": "El semen te hace madre de la patria y parirás poetas, el té hará quel ombligo regrese al comienzo, pero el río es un enigma (anagrama oír ... o ... i ... r..." (76). Al igual que la Corteja de la Vida, Ola Sola se identifica aquí con el territorio, el cuerpo, la página en blanco ["metió los dedos en la doncellez de armiño de la poesia"] en que se inscribe la escritura fálica del autor y, a la vez, como señalamos anteriormente, con la tradición poética misma: es el velo, la "telita divina", el himen que el escritor hombre tiene que vencer para acceder a la tradición y sus secretos. Finalmente, así como el Conde Carlos monta el "caballo amarillo" del relato cortazariano "El perseguidor" para penetrar a Ola

\footnotetext{
${ }^{24}$ Escrito sobre un cuerpo (Buenos Aires: Sudamericana, 1969) 52.

${ }^{26}$ Yocahú es la divinidad masculina suprema del panteón religioso de los indios aruacos o taínos de Puerto Rico. Entre los artefactos de esta cultura que se conservan, se encuentran las llamadas "piedras enigmáticas": el collar de piedra, el codo de piedra y la piedra de tres puntas. Estas últimas dos parecen indicar, según Loida Figueroa, un culto fálico. En Breve historia de Puerto Rico (Río Piedras: Editorial Edil, 1969) 29-44.

${ }^{26}$ (En "Inventario ..." (El cuento ..., 73) se citan las siguientes palabras del artista Johnny Carter, protagonista del relato cortazariano, "El perseguidor", y se le atribuyen a Cortázar: "Yo no soy más que un pobre caballo amarillo, y nadie, nadie, limpiará las lágrimas de mis ojos" (Ceremonias, 253).
} 
Sola; el autor Cortázar, haciendo las veces del protagonista de su relato "Laisla a mediodía", viaja en avión a la es(cena) final para tomar posesión de la isla que ve a distancia y del cuerpo de la Corteja de la Vida que se identifica con ella.

Cuerpos fetichizados, los cuerpos de la Corteja de la Vida y Ola Sola son, conforme a Freud, cuerpos femeninos castrados, des-membrados, sobre los que se levanta, como sustituto, el símbolo fálico. ${ }^{27}$ Sobre estos cuerpos desmembrados, todos los personajes "femeninos" y "masculinos" de "Inventario ..." fundan las posiciones subjetivas y las prácticas que los definen; instalan el condimento, el maquillaje, el tajo, el tatuaje y la grafía como fetiche, como falo. Reducida por sinécdoque a sus tetas de silicona, la Corteja de la Vida se identifica, como señalamos, con la isla de Puerto Rico, reducida, también por sinécdoque, a las montañas de la Cordillera Central popularmente conocidas como las Tetas de Cayey. Muerta de cáncer en los senos, muerta a la que le cortaron "teta a teta la existencia" (71), muerta que "murió, ya se sabe, en despecho total" (75), sus ritos fúnebres podrían describirse como la representación obsesionada de una es(cena) de castración, como el cercenamiento de sus tetas y la sustitución de éstas por las Tetas de Cayey, equiparadas aquí con inmensos falos volcánicos. Identificado con la isla de Puerto Rico, el cuerpo castrado de la Corteja de la Vida sustenta pues, como símbolo fálico, además de las posiciones subjetivas y las prácticas culturales de los personajes del cuento, el tótem, el rdolo, la imagen nacional en que se transformará su cuerpo: el fungiforme bicho de Yocahú y/o las fálicas Tetas de Cayey. Al comienzo de "Inventario ...", se consigna que la emperatriz china, "adoradora ingrata de Atabex", construye un monumento en La Puntita al "fungiforme bicho de Yocahư" (72), dios supremo del panteón taíno. Todo "Inventario ..." podria concebirse, a partir de esta descripción, como el paso del culto a Atabex, máxima diosa taína, al de Yocahú; como la dramatización de la transformación violenta del cuerpo de la madre, del matriarcado, por el nuevo tótem, por la Ley Paterna. Lo indígena, lo nacional, lo autóctono se definiria entonces, al igual que las posiciones subjetivas y prácticas culturales de los personajes del cuento, como la castración, el desmembramiento del cuerpo femenino y su conversión en falo, fetiche, valor de cambio; o como su disgregación y reconstitución en torno al nuevo ídolo, al símbolo fálico. A diferencia de Gautier Benítez, cuyo poema fundacional de la nacionalidad puertorriqueña, "Puerto Rico", identifica la isla de Puerto Rico con una india, convirtiéndola en "joyel", en artificiosa naturaleza que espera la posesión del conquistador-poeta; ${ }^{28}$ Ramos Otero nos la representa como el cadáver mutilado de la Corteja de la Vida. Al representarla así, el escritor expone la violencia de la transformación del cuerpo femenino en fetiche que sirve de base a la retórica nacional y a la tradición poética; la supresión sobre

${ }^{27}$ "Fetishism", The Complete Psychological Works of Sigmund Freud XXI (1927-31) (Londres: The Hogarth Press and The Institute of Psycho-Analysis, 1961) 149-157.

${ }^{28}$ En las estrofas finales de "Puerto Rico", Poesias (San Juan: Campos, 1929) 202. 
la que se levanta la identidad nacional, personal y poética; el silencio que le permite al poeta hablar en nombre de sí mismo y de la patria. Modificando el comentario de Jacques Vaché a André Breton, citado en Rayuela ("Rien ne vous tue un homme comme d'être obligé de représenter un pays."), la narrativa de Ramos Otero nos permite concluir con mayor propiedad que nada mata más a una mujer que representar un país, que sustentar la "tierra del Padre", ${ }^{29}$ la patria.

\section{"y yo su esclavo he dicho"}

Hasta aquí hemos visto cómo los personajes de "Inventario ..." representan no sólo posiciones subjetivas "femeninas" sino también prácticas culturales marginadas, consideradas femeninas en la sociedad boricua. Desde estas posiciones y prácticas, personajes como Carmen Cachete, Ola Sola, la emperatriz china y el propio cuentero Ramos, lectores todos de Cortázar, invocan el término dominante de las oposiciones binarias patriarcales, el verbo fálico del autor Cortázar. Si bien estos personajes asumen una posición pasiva, literalmente de "lectores hembra", frente a Cortázar; preparan también activa y conscientemente el rito, la ceremonia para que su autoridad fálica, su autoría, incida en ellos, los penetre. Al igual que en otro relato de Ramos Otero, "Vida ejemplar del esclavo y el señor", el narrador protagonista desempeña el papel sumiso de "esclavo" en una sesión "masoquista" de manera activa y dominante, ${ }^{30}$ según lo demuestra el uso del imperativo: "y yo su esclavo he dicho: oríname la vida ono me orines. Oríname el intersticio violeta de las nalgas solitarias. Oríname las venas canales de todas las islas construidas sobre el agua"; 31 en "Inventario" los personajes fragmentan y arman, desarticulan y combinan los textos de Cortázar, en una especie de bricolage digno del mejor "lector cómplice", para crear una ceremonia que concite el paso de su avión fálico sobre la isla de Puerto Rico. Utilizando el método de lectura lúdicro, activo propuesto por Cortázar, los personajes de "Inventario" eligen perversamente la pasividad; insisten en la posición subalterna en la protonarrativa genérica, sexual que fundamenta la pluralidad de sentidos de sus obras, en lo que podríamos llamar, conforme a Fredric Jameson, el "ideologema", la antinomia conceptual u oposición interesada en torno a la cual se generan sus textos..$^{32}$ De esta manera, la lectura de los personajes de

\footnotetext{
${ }^{29}$ Expresión utilizada por Rosario Ferré en el poema "Eva María" de Papeles de Pandora (México: Joaquín Mortiz, 1976) 16.

${ }^{30}$ Para una interpretación del "masoquismo" acorde con la que presenta aquí Ramos Otero, ver Gilles Deleuze, "Coldness and Cruelty", Massochism (Nueva York: Zone Books, 1989).

${ }^{31}$ Apalabramiento: Diez cuentistas puertorriqueños de hoy (Hanover: Ediciones del Norte, 1983), 42. Selección y prologo de Efraín Barradas. Enfasis mío.

32 The Political Unconscious: Narrative as a Socially Symbolic Act (Ithaca: Cornell University Press, 1981), en particular 87 y 128.
} 
"Inventario ..." reproduce insistentemente lo que Doris Sommer ha denominado los "linguistic patterns as traps or no-win games" (66) que subyacen el aparente ludismo, la polisemia infinita de la escritura cortazariana del período que ella ha catalogado como existencialista. Como la escritura cortazariana de este período, los modelos de lectura en "Inventario" —el tarot, la adivinación por medio de la baraja, el confucionismo kitsch, la magia-invocan una apariencia azarosa que culmina inevitablemente en ceremonia, en lo que, oponiendo el rito al juego, Lévi-Strauss llama su final siempre repetible, minuciosamente previsto. ${ }^{33}$ Asi, oscilan entre el ludismo aparencial y el intento de fijar el azar, de conjurarlo, como veremos, por medio del espiritismo, la comunión, el sacrificio religioso y la violación ritual.

Tras el ludismo plurivalente de "Inventario ..." se urde la protonarrativa genérica, sexual en que se concibe la escritura como la actividad creadora de la pluma-falo sobre la página-vagina; en que se equivale el acceso al lenguaje, la escritura, lo simbólico, como en Lacan, con el acceso a lo fálico. Tras su dialogismo, su polisemia, se repite obsesionadamente la misma protonarrativa genérica basada en la oposición entre la actividad masculina y la receptividad femenina. Esta se destaca sobre todo en tres escenas paralelas, dos de las cuales hemos comentado anteriormente: la ceremonia fúnebre de la Corteja de la Vida (en particular, 85), la violación-asesinato de la poet(is)a Ola Sola (84-85) y, según veremos, la penetración del cuentero Ramos por las palabras fálicas de Cortázar (82-84).

Recurriendo al espiritismo, la comunión, el sacrificio religioso y la violación ritual como modelos formales, la ceremonia fúnebre de la Corteja de la Vida dramatiza el proceso de la significación, el acceso a la escritura como un rito de paso, como una transformación. En ella, la significación se concibe, como en estos modelos, como el tránsito violento de la vida a la muerte, de lo real, material, corporal a la letra; como el desmembramiento del cuerpo y su sustitución por el Símbolo, la Idea, la escritura fálica. Ya hemos visto cómo el cuerpo de la Corteja de la Vida es ingerido, cortado, tajado y tatuado por las prácticas culturales de los personajes de "Inventario ..." y cómo sobre su cuerpo excluido, borrado, se erigen estas mismas prácticas culturales como fetiches, falos. La condimentación de Carmen Cachete, el maquillaje de la emperatriz china y el tatuaje del cuentero Ramos se instauran todos, como escritura fálica, sobre el cuerpo previamente suprimido de la Corteja de la Vida. A la vez, asumiendo la posición "femenina", pasiva de la Corteja de la Vida, estos personajes invocan, mediante una lectura "cómplice", activa, de los relatos de Cortázar, la comparecencia del otro, del autor Cortázar. Reuniendo sus obras sobre el cuerpo de la Corteja de la Vida y seleccionando pasajes salteados, como se recomienda en Rayuela, los personajes construyen una trama para convocarlo

\footnotetext{
${ }^{39}$ En "Cultural Discontinuity and Economic and Social Development", Structural An-
} thropology II (Nueva York: Basic Book, 1976) 319-320. 
y atraparlo, para atraer el "hongo oculto de su glande" (83) al cuerpo de la Corteja de la Vida. Así como ya hemos visto, uno de sus avatares, el Conde Carlos monta el "caballo amarillo" del relato cortazariano "El perseguidor" para asesinar-penetrar a la poet(is)a Ola Sola; Cortázar viaja en avión a cumplir la ceremonia fúnebre, la protonarrativa genérica, a tajar y violar el cuerpo de la Corteja de la Vida y erigir sobre él su verbo, su autoridad fálica. El proceso de la significación que dramatiza esta ceremonia fúnebre de la Corteja de la Vida se puede definir entonces, como en Lacan, como la ruptura violenta del sujeto consigo mismo, con la plenitud del ser, efectuada por el falo significante o lo que Lacan llama el Significante del Falo, que funciona, a la vez, como barra que separa el significante del significado, al sujeto cultural, lingüístico del sujeto como ente real no representable y como tótem que ocupa y organiza el cuerpo suprimido, desmembrado, idolo o fetiche en que encarna la Ley del Padre, los privilegios del patriarcado. ${ }^{34}$

La escena de la violación de la poet(is)a Ola Sola por el Conde Carlos configura también el proceso de la significación como un asesinato o sacrificio ritual, como el desmembramiento y ocupación del cuerpo por el Significante del Falo. Conjugando el tarot y la mitología taína, Ola Sola invoca al Conde Carlos, caballero de la baraja taína, "macho machete", para que, "mano en bicho de piedra" (84), en "fungiforme Yocahú", la penetre, la asesine, la taje. El Conde Carlos no sólo representa aquí un naipe de una inventada baraja taína sino que, como indicamos, cabalga también el "caballo amarillo" que, en el relato cortazariano "El perseguidor", se identifica con el autor, el artista. Asi se equivalen el Conde Carlos y Cortázar: como el Conde Carlos penetra-asesina a Ola Sola; Cortázar, conforme a la letra del bolero "Usted", "[la] desespera, [la] mata, [la] enloquece" (73). Mediante una lectura "cómplice", activa de las obras de Cortázar, Ola Sola convoca, como los otros personajes que participan en la ceremonia fúnebre de la Corteja de la Vida, la presencia de Cortázar en la figura del Conde Carlos, su autoría. La pluma del autor Cortázar, su palabra, lo que Edward Said ha llamado el poder de procrear que se arroga el escritor en la "tradición occidental", ${ }^{35}$ se equipara aquí entonces con el arma cortante del Conde Carlos, con el "fungiforme bicho de Yocahú" (72), que funciona, a la vez, conforme al concepto lacaniano del Falo, como instrumento del asesinato y de la fecundación, que separa al sujeto de sí mismo y se instala como tótem que organiza el cuerpo, su re-presentación. Al convocar, mediante la lectura, el poder fálico del Conde Carlos-Cortázar, Ola Sola, que se identifica, como vimos, con la página virgen y la musa-madre del paradigma de la "ansiedad de la influencia" de Bloom, invita no sólo la placentera tortura del desmembramiento sino también su otra cara: su poder, como explica Said, para acceder a la

${ }^{34}$ Véase "Desire and the Interpretation of Desire in Hamlet" (trad. de James Hulbert, Yale French Studies 55/56 [1977]) 28; y "The Signification of the Phallus" (trad. de Alan Sheridan, Ecrits: A Selection [Nueva York: W. W. Norton and Company, 1977) 287. as Véase "The Novel as Beginning Intention", Beginnings: Intention and Method 83. 
tradición literaria y para fecundarla, aumentarla. Leyendo los naipes del tarot taíno al azar, la emperatriz china le revela a Ola Sola la protonarrativa genérica que es su destino: "sabrás que el Conde Carlos cabalga en su caballo amarillo y que viene a buscarte ... [con su] bicho de piedra" (74), bicho de piedra cuya potencia fecundadora, seminal, le predice la emperatriz china, "te ha[rá] madre de la patria y parirás poetas" (76).

La relación que establecen, en las dos escenas anteriores, la Corteja de la Vida, Ola Sola y demás personajes "femeninos" de "Inventario ..." con el Conde Carlos-Cortázar; se reproduce también en la que quizás sea la relación más importante del cuento: la del cuentero Ramos con el autor Cortázar. Como en aquellas dos escenas, en ésta el asesinato, el sacrificio religioso y la violación ritual dramatizan el proceso de la escritura, de la significación. Recurriendo a la forma fúnebre litúrgica de la letania, esta escena define el Significante del Falo, "fungiforme Yocahú", como en Lacan, como el instrumento, barra o arma que efectúa la ruptura del sujeto consigo mismo, su escisión:

fungiforme Yocahú, arma del suicidio, placer de las cuatro patas, verdugo del pollito frito, sacerdote de la misa negra, puñal del asesino, penitencia divina, templo del iry venir, víspera de la muerte, árbol de la oscuridad, último recuerdo del ahogado, por la boca murib el pescado, fungiforme Yocahú (82-83).

Conjugando metáforas alusivas al suicidio, asesinato o sacrificio ritual ("arma del suicidio,... sacerdote de la misa negra, puñal del asesino, penitencia divina, templo del ir y venir, víspera de la muerte, ... último recuerdo del ahogado") con otras alusivas, en argot puertorriqueño, a la sodomía y la fellatio ("placer de las cuatro patas, verdugo del pollito frito, ... por la boca murió el pescado"); la escena equivale el asesinato, el sacrificio ritual, la ruptura del sujeto consigo mismo en aras de la significación, a la penetración, la violación. Como en la liturgia fúnebre, esta letanía también es una invocación. Así como Ola Sola y los demás personajes "femeninos" provocan, mediante una lectura "cómplice" activa, la comparecencia del Conde Carlos-Cortázar, el cuentero Ramos incita, mediante la lectura, su asesinato-penetración por el verbo fálico del autor. Leyendo los relatos de Cortázar, el cuentero siente que las palabras, una a una, "se le met[en] adentro como una sólida columna" y van "creciendo [como] un eje metido por los ojos que conecta[...] con la puerta de la muerte, el altar de fungiforme Yocahú" (83). Equiparadas con "fungiforme Yocahú", las palabras de Cortázar no sólo escinden al cuentero Ramos sino que también lo sustituyen, lo poseen, ocupan su cuerpo. Ocupado por la escritura de Cortázar, el cuerpo del cuentero Ramos se transforma en texto y queda inscrito, al finalizar esta escena, en el relato cortazariano "La isla a mediodía". Como el protagonista de su relato, Cortázar divisa entonces, desde la ventanilla de un avión, al cuentero Ramos y a los personajes "femeninos" del cuento:

'la realidad queda invadida por lo otro', leyo en el recorte del periódico y cuando miro por la ventanilla divisó a lo lejos el caney de la emperatriz china y en la 
ventana abierta, nosotros viendo a la Corteja de la Vida llegando a la tumba prometida (84).

\section{Para virar al macho: Desplazamiento e inversión}

Si bien los personajes "femeninos" de "Inventario ..." y el cuentero Ramos asumen una posición pasiva e invocan, mediante una lectura "cómplice", activa y las prácticas culturales subalternas que representan - la cocina criolla, la domesticidad, la poesía como expresión de la intimidad, el espiritismo, la nigromancia y otras formas de conocimiento intuitivas y esotéricas- lo que hemos llamado la protonarrativa genérica, sexual que subyace los textos "existencialistas" de Cortázar; también subvierten subreptciamente esta protonarrativa. La lectura y prácticas culturales de los personajes de "Inventario ..." intentan, por un lado, acceder a la (autor)idad, al poder de la escritura, conjurando el verbo fálico del autor, su penetración, su asesinato; pero también pretenden, a su vez, urdir una trama-trampa para penetrarlo, asesinarlo, virarlo. Quizás el ejemplo más claro o extremo de este proceder esté cifrado, en “Inventario ...", en la figura de la Corteja de la Vida, para quien la asunción de la pasividad a ultranza - la muerte- constituye, como en el narradorprotagonista de "Vida ejemplar del esclavo y el señor", citado anteriormente, una forma de dominio. Por medio de su pasividad, la Corteja de la Vida logra concitar y controlar no sólo a los personajes del relato sino también al autor Cortázar a quien atrae para poseerlo, a quien tiene literalmente "agarrado por el hongo culto de su glande":

La Corteja de la Vida había regresado inesperadamente muerta para hacernos probar su pacto con el tiempo (con la vida muerta y con la muerta en vida sobretodo) queriéndose morir para que los demás tuviéramos que sentir su muerte, para que ella misma tuviera el placer espontáneo del suicidio planeado, tener el control de la muerte y no tenerlo, como ahora en el caney de la emperatriz china tenía, al asesinado no asesinado todavía [al autor Cortázar], agarrado por el hongo culto de su glande, oculto entre las portadas de la Quinta Edición ... (83).

Aunque son los personajes "femeninos" de "Inventario ..." y el cuentero quienes son, como vimos, asesinados y penetrados por el verbo fálico del autor; hay, desde el principio del cuento, indicaciones de la intención de asesinar al autor mediante la lectura, mediante una ceremonia fúnebre que se desdobla en cortazariano Club de la Serpiente camp, de un velorio que también es velada. Quizás en quien más claramente se evidencia esta intención de subvertir la posición privilegiada del autor poseyéndolo, asesinándolo, sea en el cuentero Ramos. Ya vimos cómo el cuentero, al igual que la Corteja de la Vida, Ola Sola y demás personajes "femeninos" de "Inventario", es poseído, en tanto lector, por las palabras del autor, constituidas en Significante del Falo. Pero también, en 
tanto escritor, el cuentero pretende, a su vez, penetrar, poseer, arrogarse el poder fálico del autor para nombrar, engendrar la significación. Se establece entonces entre él y Cortázar una lucha por la paternidad, por la autoría de unos mismos textos. La emperatriz china presenta esta lucha al exhortar al cuentero: “... tú no puedes seguir jodío en el anonimato de la lengua sabiendo que todo lo que te cuenta el morocho tanguero es tuyo, tú no puedes seguir poniéndole manuscritos en el bolsillo" (79). Más adelante el cuentero, al abrir un libro de Cortázar, descubre en él "el cuento que yo hubiera escrito el Añoviejo próximo" (81). Conforme al concepto de la escritura como una actividad fálica, esta lucha por la autoridad se representa en términos sexuales: "El problema era que lo quería porque lo quería a él, el asesino enamorado del asesinado .... Me estoy heterosexualizando, pensó, ¿se homosexualizará el otro? ¿se cortaría Ramos? ¿se ramificaría Cortázar?" (subrayado mío, 81). A diferencia del esquema edípico de la "ansiedad de la influencia" de Bloom, el cuentero no trata aquí simplemente de asesinar al precursor literario, al autor padre, de suplantarlo, para poseer la tradición poética convertida en musa-madre; sino de penetrar al autor mismo, de poseerlo; de virarlo.

Esta intención de virar, de subvertir y cancelar el poder fálico de Cortázar se evidencia también en los demás personajes "femeninos" del cuento. Narrada en gran parte en tercera persona, la ceremonia fúnebre de la Corteja de la Vida se propone como una conspiración, un atentado: "Tenemos que matarlo porque sí, por ser el otro [el autor Cortázar]" (75). Más adelante, asumiendo la perspectiva de los integrantes de la ceremonia fúnebre, el cuentero analiza y planea: "este hombre nos suicida con cada tango que escribe, ya es hora de que al son de la plena baile" (subrayado mío, 81). En otro lugar, citando de "Las armas secretas", la narración se refiere a Cortázar: "También quiso saber por qué íbamos a liquidarlo, y se lo explicamos, vaya si se lo explicamos" (74; Ceremonias, 295). Si bien los personajes participantes en la ceremonia fúnebre asumen, como vimos, una posición pasiva, literalmente de lectores hembra, frente al autor Cortázar, también traman el atentado, la confabulación. Por un lado, suscitan el poder fálico del autor y, por otro, lo minan mediante una lectura salteada que va identificando subrepticiamente a Cortázar con personajes suyos que se descentran, se desdoblan y mueren y con tramas concebidas como juegos, o lo que Sommer llama dead-end plots o no-win games $(66,75)$, que llevan indefectiblemente a la pérdida o la muerte. La cita anterior, por ejemplo, identifica a Cortázar con el protagonista de "Las armas secretas", Pierre, en cuya vida irrumpe un pasado que él, sin proponérselo, revive. Su novia Michèle había sido violada en la infancia por un soldado nazi, y Pierre, sin saberlo, se desdobla en este soldado y la ultraja. Al desdoblarse y repetir el pasado, Pierre cumple la "ceremonia", el "juego" que lo conducirá a la muerte: la escena final en que será, como lo había sido el soldado nazi, ajusticiado por los amigos de Michèle. Otra cita, esta vez de "Instrucciones para John Howell" de Todos los fuegos el fuego, le atribuye las palabras de Eva, personaje de una pieza teatral 
que se presenta en el cuento, a Cortázar: "No dejes que me maten" (83; Todos los fuegos ..., 106). Con estas palabras, Eva, quien se encuentra presa del desarrollo lingüístico de la pieza, intenta comunicarse con el protagonista, Rice, a quien han sacado del público y conminado a hacer en escena el papel de su esposo, John Howell, para que intervenga en la obra y altere su final, final que culminará previsiblemente en su muerte doble, como personaje y persona. Rice trata de modificar este final alterando la configuración lingüística de la obra, pero fracasa. Al finalizar la pieza, Rice, nuevamente en el público, observa el asesinato inevitable de Eva y, al igual que el presunto culpable en escena, John Howell, se da a la fuga. Sin comprender por qué huye, Rice presiente que está, como Eva, preso de la ficción teatral, de una "ceremonia" o "juego" cuya lógica lo lleva indefectiblemente a la muerte. Otra cita identifica a Cortázar con Johnny Carter, el protagonista de "El perseguidor": "Y yo no soy nada más que un pobre caballo amarillo, y nadie, nadie, limpiará las lágrimas de mis ojos" (73; Ceremonias, 253). Estas palabras, dichas por Carter en ocasión de la muerte de su hija, remiten a una de sus divagaciones en la cual se cuenta la historia de unos "caballos salvajes" (Ceremonias, 226). En el cuento, Johnny es, a la vez, el saxofonista brillante cuya música pretende abolir los hábitos, el tiempo lineal, lo preconcebido, verdadero "caballo salvaje" que se niega a dejarse domesticar, y el mediocre hombre fracasado que no entiende su propia búsqueda ontológicomusical, que no es sino: "el fantasma de otro Johnny que pudo ser, y ese otro Johnny está lleno de grandeza“ (251). Esta contradicción, este desdoblamiento, lo va desgastando hasta conducirlo a la muerte. Finalmente, una serie de alusiones y citas identifican a Cortázar con Marini, el protagonista de "La isla a mediodía". Como éste, Cortázar contempla, en "Inventario ...", desde la ventanilla de un avión, una isla que es, a la vez, la isla de su relato ("la isla tenía una forma inconfundible, como una tortuga que sacara apenas las patas del agua" $[84 ;$ Todos los fuegos ..., 94]) y la isla de Puerto Rico, isla de los personajes del cuento de Ramos Otero ("esperábamos envueltos en un ruido de nubes rotas el avión ... cruzando entre las tetas de piedra, acercando más al asesinado [a Cortázar] a su destino" [84]). Atrapado en el mundo rutinario de un steward de aerolínea, Marini, el protagonista del relato cortazariano, es sorprendido por la visión recurrente de una isla que se divisa siempre, desde la ventanilla del avión, a mediodía. Obsesionado por esta isla, que pronto cobra para él un aura mítica y onírica, Marini decide viajar a ella. Como en "Axolotl", Marini pretende atravesar el "frío cristal" de la ventanilla del avión que parece el "límite del acuario donde lentamente se $\mathrm{m}$ [ueve]" la isla como una "tortuga dorada en el espeso azul" (Todos los fuegos ..., 97). Un día que cree ver a alguien mirando el avión desde la isla, hace los trámites para el viaje, y casi sin transición, salta la narración en el tiempo, y desembarca en ella. Paseando por estaisla paradisíaca, Marini vuelve a descubrir su relación con la naturaleza y comienza a aprender, como Adán, los nombres de las cosas. De esta comunión con la naturaleza lo sustrae el ruido de un avión que cae verticalmente sobre el mar. Marini se lanza 
al agua y remolca a nado el cuerpo del único sobreviviente. Al llegar a la orilla intenta inútilmente salvarlo. Entonces acuden los habitantes de la isla, rodean el cuerpo y se preguntan cómo llegaría solo a la orilla ese cuerpo - "To único nuevo entre ellos y el mar" $(100)$. El final revela el desdoblamiento implícito en la perspectiva narrativa del cuento, su visión doble: Marini mira la isla desde la ventanilla del avión, y del otro lado del vidrio, del espejo, Marini mira el avión desde esa otra realidad que es la isla. Como en los cuentos cortazarianos citados anteriormente, el intento de escapar de lo convencional, del hábito, la rutina, descentra al protagonista y lo desdobla, desplazándolo hacia una "ceremonia" - "juego" en los cuales quedan abolidos el deslinde de lo real y lo soñado, lo verdadero y lo imaginado, el tiempo lineal y el cícilico, y el yo unitario y generador del sentido. En todos estos cuentos el protagonista se descentra, se desdobla y es, en última instancia, anulado y reemplazado por patrones lingüísticos. Estos cuentos describen una ceremonia implacable: disponen, como Borges en "La muerte y la brújula" o "El Sur", una red, una trama para atrapar al yo, aniquilarlo y dispersarlo hacia las estructuras supraindividuales, puramente lingürsticas de la narración.

Al identificar a Cortázar, mediante una lectura "cómplice", con personajes suyos que se descentran, se desdoblan y mueren y con tramas que llevan indefectiblemente a la pérdida o la muerte, los personajes "femeninos" y el cuentero Ramos preparan el reverso de la entrega al autor, la otra trama o sorpresa: su desdoblamiento o virazón. Convocado a la ceremonia fúnebre de la Corteja de la Vida a través de las prácticas subordinadas de los personajes "femeninos" de "Inventario ..." - las artes culinarias, la invocación poética, la nigromancia y el espiritismo- Cortázar, cruza, como Marini, la isla (de Puerto Rico) en avión. Su avión, como el fungiforme bicho de Yocahú que blande el Conde Carlos, es, a la vez, falo y arma; es el helicóptero que, según el poema de Cortázar citado por el cuentero ante la tumba de la Corteja de la Vida, "Blackout" de Pameos y meopas, anuncia el asesinato, "la delicada muerte por trituración" (43). Pero en ese momento en que su avión cruza la tumba de la Corteja de la Vida y la isla, en que el cadáver de la Corteja de la Vida y la isla se (con)funden; Cortázar, el penetrador-asesino, y la Corteja de la Vida, la penetrada-asesinada cambian posiciones. Como Marini, Cortázar, que mira la isla desde la ventanilla del avión, se desdobla en lo mirado, y la Corteja de la Vida, al contrario del relato cortazariano, resucita y se "larga[...] volando" (86). En tanto que la pluma, el verbo fálico de Cortázar, su avión, va perdiendo (autor)idad al transformarse, al finalizar el cuento, en "mariposa" y en "bicho de sombras" (86); la Corteja de la Vida asume plenamente la expresión: entra en la escritura volando hacia las páginas de un diario erótico, hacia su imagen, su vida, su intimidad "literarizada": "y todos sentimos que sí, que allí se largaba la Corteja de la Vida con su melena colorada cubriéndole la fase siempre oculta de la cara, las piernas apretadas como para que no entrara el aire, las manos aceleradas sobre las páginas de un diario erótico" (86). Al efectuar, mediante 
su lectura, este desdoblamiento, este viraje, los personajes "femeninos" y el cuentero logran invertir no sólo su posición de lectores-hembra con respecto al autor fálico, sino también la posición de lo reprimido con respecto a lo expresado, del cuerpo femenino silenciado con respecto a la escritura patriarcal, de la islamujer con respecto a la retórica nacional que se apropia de ella. Y, a la vez, en la medida en que este viraje se realiza mediante prácticas subordinadas, consideradas "femeninas" en la sociedad boricua, se invierte también el orden de la representación cultural puertorriqueña. Como en la escritura masoquista que comenta Deleuze, este momento de la escritura de Ramos Otero se define por el intento de asesinar al autor-padre, de penetrarlo, y de asumir lo subordinado, lo tópicamente femenino, para dotarlo de autoridad, de falo.

Pero esta inversión en la escritura de Ramos Otero es sólo un momento en una estrategia desconstructiva que culmina, como explica Spivak, en el desplazamiento. Al final, "Inventario ..." oscila entre dos posibles clausuras narrativas. A la primera la define, como vimos, la toma de la (autor)idad fálica de Cortázar por parte de los personajes "femeninos" y el cuentero. Y a la segunda la constituye el movimiento inverso: la reintegración o reinscripción de la lectura antipatriarcal de los personajes de "Inventario ..." en los textos de Cortázar. Como se anticipa ya al principio del cuento ("Todavía releyendo los libros de Cortázar encontramos que el mismo Cortázar había previsto todo" [74].), en el momento del desenlace, de la sorpresiva virazón del autor, los personajes sienten "[c]omo si alguien hubiese estado pasando todo el tiempo páginas de algún libro donde a veces quedábamos asomados como por una ventana" (86). Esta cita remite a la escena, antes comentada, en que, después de la penetración y desmembramiento del cuerpo del cuentero por las palabras fálicas del autor, los personajes quedan inscritos en el cuento cortazariano, "La isla a mediodía" (84). Por un lado, Cortázar es anulado por las estrategias de la lectura que despliegan los personajes "femeninos" y el cuentero; por otro, estas estrategias estaban ya, desde siempre, contenidas en la escritura cortazariana. "Inventario ..." puede ser interpretado, como lo hemos hecho, como la toma de la (autor)idad, del poder fálico para crear, para contar por parte de los personajes "femeninos" y sobre todo del cuentero. Las palabras finales del cuento así lo confirman: "El asesino ... pensó que ya era hora, que ya podía vestirse con la ropa de luto y ser cuentero, para contarlo todo sin omitir detalles" (86). Pero la reinscripción de los personajes, incluido el cuentero, en la textualidad cortazariana, así como el paso de la voz narrativa de un nosotros inicial a la tercera persona, permiten sugerir que la muerte a la que asiste el cuentero al final, la muerte sobre la cual se erige su escritura, no sólo es la muerte del otro, del autor Cortázar, sino también su propia muerte. La inversión de la relación jerárquica entre el creador fálico y el lector-hembra, entre el autor-padre y su "sucesor", cede entonces, como sugiere Spivak en otro contexto, a un desplazamiento hacia las relaciones mismas, hacia el campo diferencial, incesantemente reñido, desarticulado y reconstituido, que configura la (autor)idad. 
“Inventario ...” es, como señalamos, no una suma o totalización poética orgánica sino una especie de enumeración de los recur sos retóricos y narrativos de la cuentística de Ramos Otero. En él se inventarían, como vimos, algunas de la relaciones (o tensiones) narrativas fundamentales en su escritura: la relación de los personajes con el narrador, de la lectora con el autor, del autor en tanto función o personaje con el autor real, del autor en tanto obra con sus precursores. Relaciones éstas que se articulan con una serie de oposiciones binarias patriarcales que apuntalan no sólo la literatura sino también todos los otros discursos y prácticas sociales, tanto los públicos como los privados..$^{36}$ El intento de desconstruir estas relaciones y sus correspondientes articulaciones sexuales, genéricas, constituye la problemática en torno a la cual giran la mayoría de los cuentos de Ramos Otero. En ellos, como en "Inventario ...", se intenta subvertir, de maneras diversas, la naturaleza jerárquica de esas relaciones genériconarrativas. Quizás sea "Loca la de la locura", ${ }^{37}$ el relato en que se evidencia más claramente ese primer momento de la desconstrucción que Spivak define como la inversión. En él, el narrador, un cantante travestí, asume, como los personajes "femeninos" de "Inventario ...", la posición pasiva, sumisa, que le asigna a la mujer el bolero. Asumiendo esta posición, él(ella) logra atraer al otro, al penetrador, al "bugarrón" a quien "el bolero le da autoridad" (18). Pero en su intento por hacer que el bugarrón asuma la posición receptiva en el coito, por virarlo, éste se rebela, y él(ella) termina matándolo. Con esta virazón y muerte del macho, el travestí toma conciencia y se vuelve revolucionario(a): "Ahora estoy sin máscaras. Con un puñal de huesos para unirme a la revolución" (19). Al virar al macho, el travestí subvierte no sólo la autoridad fálica del bugarrón sino también las oposiciones binarias jerárquicas que, en la cultura popular puertorriqueña, sustentan esa autoridad. En otros cuentos de Ramos Otero, la inversión es sucedida por lo que, conforme a Spivak, hemos definido como el segundo momento de la desconstrucción: el desplazamiento. Esta desconstrucción -con su movimiento doble de inversión y desplazamiento-se podría trazar en la escritura de Ramos Otero comentando, por ejemplo, un relato de cada uno de sus libros de cuentos.

En "Hollywood Memorabilia" de su primer libro, Concierto ..., la oposición entre el autor-narrador como creador, como Dios ("Yo soy Dios" [78].), y lo creado se invierte cuando, al finalizar el cuento, el narrador, quien también es

\footnotetext{
${ }^{36}$ Refiriéndose a la crítica de José Luis González de no insertar su experiencia erótica en un "contexto superior" (Arcadio Draz Quiñones, Conversación con José Luis González [Río Piedras, Huracán, 1977], 47), Ramos Otero afirma la naturaleza "superior", pública o política de la sexualidad: "Entendiendo que en la cama se libra una de las batallas políticas más crueles, supe que la única alternativa que me quedaba (por más que la evadiera) era regresar a la historia de amor y desquitarme con la inquisicion de la literatura portorricensis" (Página en blanco y stacatto, 102-103).

${ }^{37}$ Publicado originalmente en Reintegro de las Artes y la Cultura 1, 2(1980) 18-19; recogido en Cuentos de buena tinta, 233-240.
} 
proyectante de cine, comienza a desintegrarse físicamente "en átomos constantes de luz" (85) para reconstituirse en lo proyectado, en la creación: imágenes de las estrellas femeninas de Hollywood de los años 30 y 40: West, Garbo, Swanson, Leigh, Crawford, Hayworth, Davis. Esta inversión, que es además una inversión sexual, conlleva, como en "Inventario ...", la muerte del autor. Pero, al igual que en éste, el triunfo del personaje sobre el autor, de la ilusión cinematográfica sobre la realidad, queda rápidamente anulado al reconocerse que las imágenes en que se convierte el autor son imágenes de estas estrellas en el momento de la muerte:

Porque tengo veinte $y$ tres años y pienso que moriré con un ataque imprevisto de tuberculosis (como Greta Garbo en Camille) (77).

Voy a morir a los treinta arrollado por un vehículo de transportación (como Vivien Leigh in Waterloo Bridge) (79).

Por eso creo que moriré a los treinta muy violentamente (como Rita Hayworth en The Lady from Shanghai) (81).

Anulada la superioridad de ambos polos de la oposición, la inversión del autor en personaje se desplaza entonces hacia el texto mismo, hacia sus múltiples relaciones diferenciales.

En "El cuento de la Mujer del Mar", el narrador, el "cuentero", relata a su amante, Angelo, la historia de la Mujer del Mar, la poeta manatieña Palmira Parés. Basándose en la biografía de la poeta puertorriqueña Julia de Burgos y fundiéndola con la de Ramos Otero, el cuentero narra, como Scherezade, la historia de Palmira Parés para evitar la muerte o sus equivalentes: la soledad, la ausencia del amante, su partida. Identificado, como Schariar, el rey misógino de Las mil y una noche, con la muerte, el amante oyente es el otro, el penetrador, el asesino. Como en "Inventario ...", el cuentero urde una trama, inventa un cuento - "El cuento de la Mujer del Mar" - para atraer al amante oyente, atraparlo, desarmarlo y matarlo. Contar el cuento es retener al amante pero también inmovilizarlo, eternizarlo, matarlo, es absorberlo o inscribirlo en la madeja impersonal de la escritura: "si supiera que para él y su horizonte de dragones inventé una mujer (las mil y una noches de su amor y la tarde inevitable de su muerte) y organicé con paciencia de anémona sus ritos funerales" (106). Si bien hay, desde esta perspectiva, una inversión: el cuentero asesina al oyente que lo va a asesinar; esta inversión se desconstruye al revelarse que Angelo, el amante, también es cuentero: narra la historia de Vicenza Vitale, "The Story of the Woman of the Sea", de la "Donna del Mare". Entonces el uno es para el otro el cuentero; el otro es para el uno el oyente, $y$ "El cuento de la Mujer del Mar" es el cuento que ambos elaboran ("Y entre nosotros se alarga como un puente invisible la Mujer del Mar" [103]), la zona especular donde ambos se encuentran, se enfrentan e intercambian papeles 
incesantemente: "la calle Cristóbal, la de los dragones de fuego, y detrás de los biombos de seda, el cuentero y el enano napolitano [el amante Angelo] a cada lado del espejo" (103). Así como el amante-oyente es asesinado por el cuentero, el cuentero es, a su vez, asesinado por el amante-oyente y absorbido por el texto: "Nada lo salvará [al cuentero] de sólo ser recordado por "El cuento de la Mujer del Mar", encerrado para siempre entre el comienzo y el final de un cuento infinito, sepultado en el amor de las palabras, detrás de la portada de su foto (como una lápida) $^{\prime}(104)$. Paralelamente, el relato del cuentero y su amante y el cuento narrado por ellos, "El cuento de la Mujer del Mar", se espejean; se vuelven indistinguibles. Al igual que el cuentero espera al amante; en el cuento narrado, Palmira Parés, la Mujer del Mar/Donna del Mare, espera a su doble, a la otra, a la amante asesina en que se convertirá. Palmira Parés/Vicenza Vitale, las dos nacidas, como Ramos Otero, en ciudades de la costa -Nápoles, Manatí, Puerto Rico-y exiliadas frente al mar -Montreal, Nueva York- se desdoblan en la mujer que las mira desde el otro lado del espejo: la Filí-Melé de Palés(Parés) Matos. Conjugando dos poemas, "Puerta al tiempo en tres voces" de Luis Palés Matos y "Entre mi voz y el tiempo" de Julia de Burgos, ${ }^{38}$ poemas cuyos títulos mismos se espejean, Ramos Oteroconstruye un relato que gira en torno a la especularidad. Palmira Parés es, como la voz lírica del poema de Burgos, la que va a cruzar el espejo/mar/ribera de la muerte, para encontrarse consigo misma, con su otro yo, con la poeta: "En la ribera de la muerte,/ hay algo, / alguna voz $/$ alguna vela a punto de partir $/$... En la ribera de la muerte, / itan cerca!, en la ribera/ (que es como contemplarme en un espejo)"(124). Y Filí-Melé es la "imagen" de lo "inaprehensible" poético que viene, según el poema de Palés Matos, del otro lado de ese espejo/mar/ribera: "Filí, la inaprehensible ya atrapada/ Melé, numen y esencia de la muerte./ Y ahora, ¿a qué trasmundo, perseguida/ serás, si es que eres? ¿Para qué riberal huye tu blanca vela distendida/ sobre mares oleados de quimera?" (571). Tanto el cuentero como el amante oyente se identifican alternadamente con la Mujer del Mar y con FilíMelé. Por momentos, el cuentero es la Mujer del Mar, y el amante el que viene del otro lado del espejo a matarlo. En otros, el amante es la Donna del Mare, y el cuentero el que llega de la otra ribera del espejo para matarlo, para inscribirlo en su texto. El cuentero amante, el oyente amado y el mismo Ramos Otero, como autor, en la medida en que su biografía se funde con la de la Mujer del Mar, son todos, como la voz lírica del poema de Burgos, el hablante poético que se desintegra y se dispersa, que prepara sus propios ritos fúnebres para desaparecer en la galería de espejos del texto-poema. Loque podría interpretarse al principio

${ }^{38}$ Luis Palés Matos, Obras (1914-1959): Tomo I: Poesta (Río Piedras: Universidad de Puerto Rico, 1984), 571-73. Edición al cuidado de Margot Arce de Vázquez; introducción de Federico de Onís. Julia de Burgos, Yo misma fui mi ruta (Río Piedras: Huracán, 1986) 124. Edición al cuidado de María M. Solá. 
como una inversión de las relaciones jerárquicas del texto cede entonces, al final, al desplazamiento infinito de sus múltiples relaciones diferenciales.

En "Página en blanco y stacatto", del libro del mismo título, el narrador, el escritor Ramos, va, como en "El cuento de la Mujer del Mar", al encuentro del personaje-amante que lo asesinará. Inventándole una historia a su personaje, Sam Fat, Ramos logra atraerlo al bar de Loisaida, Nueva York, donde se realizará el asesinato. En la historia del escritor, Sam Fat es un sacerdote santero o "babalao" de origen chino-boricua, descendiente de una hija de Yemayá, la Madama Candelas, cuyo nombre guarda el secreto de un antiguo agravio: en el siglo XVI puertorriqueño una hija de Yemayá había sido quemada en la hoguera por el inquisidor católico, el obispo Nicolás Ramos de los Santos. Ahora, a fines del siglo XX, en Nueva York, Sam Fat, babalao e hijo de la deidad africana, Orunla, "maestro del pasado, presente y futuro" (81), se ve obligado a vengar el agravio. Asumiendo la historia de persecución de sus antepasados, Sam Fat decide buscar una víctima para vindicarlos. Es entonces que Sam, el vengador de los perseguidos, se transforma en detective, en perseguidor, en victimario: le tiende una trampa al escritor puertorriqueño "mitómano" y "deformador de la historia" (85), Ramos; y el escritor Ramos, quien, a su vez, asume el papel del antiguo inquisidor, el obispo Ramos, se convierte en la víctima, en el perseguido. Al final, el personaje-amado Sam Fat atrapa al escritor-amante Ramos, invirtiendo así la relación jerárquica principal del cuento. Pero entonces se revela que el asesinato había sido organizado por el mismo Ramos; y Sam Fat, el perseguido perseguidor, se transforma nuevamente en perseguido en tanto que el escritor Ramos, el perseguidor perseguido, se convierte, por última vez, en perseguidor muerto, en ganador derrotado. En "Página en blanco y stacatto", como en "Inventario ...", los dos polos de las oposiciones jerárquicas personaje-escritor, ficción-historia, quedan, al final, anulados, y se desplaza la narración hacia las relaciones textuales mismas, hacia su incesante desconstrucción.

La autobiografia como punto de referencia obligado de la cuentística de Ramos Otero obedece, como hemos visto, no tanto a un intento de revelar un yo profundo, un yo verdadero, sino a un intento de indagación y cuestionamiento del yo, de su autoridad para originar y dotar de sentido el texto. Así como ha señalado Linda Hutcheon en relación con la literatura de la metaficción o lo que ella llama la "narrativa narcisista", ${ }^{39}$ en la cuentística de Ramos Otero este cuestionamiento se manifiesta, por un lado, en el desplazamiento y dispersión del yo hacia las relaciones que sustentan la escritura; hacia la relación, por ejemplo, entre el autor y la lectora, el autor y sus personajes, el autor y sus precursores. Se manifiesta también, por otro, en la subversión del género que cuenta, en su doble acepción; en la anulación del yo paterno que escribe y de la

${ }^{39}$ Ver en particular "Composite Identity: The Reader, the Writer, the Critic", Narcissistic Narrative: The Metafictional Paradox (Nueva York: Methuen, 1980) 138-52. 
metáfora fálica que fundamenta su escritura. Como hemos comprobado, en sus cuentos, la pluma-falo unitaria que valida la (autor)idad se transforma, al igual que el yo unitario del autor, en lo diferencial, en lo múltiple, en lo que el texto no oculta sinoque exhibe, ostenta: las "plumas". En la literatura puertorriqueña, este doble cuestionamiento - textual, genérico- de la escritura de Ramos Otero no sólo marca, como hemos señalado, una ruptura con el yo patriarcal, autoritario de la generación del 50 , sino que rompe también, en términos más generales, con un discurso de formación nacional que convierte la patria en mujer para poseerla y contenerla, para hablar en su nombre o escribir sobre ella, discurso que, al constituir la nación, nos constituye. Así como poetas como Gautier y Corretjer erigen literalmente su alabanza fálica sobre la patria mujer, la patria-amada, ${ }^{40}$ Ramos Otero nos la presenta como las dos Tetas de Cayey, como el cadáver "despechado" de la Corteja de la Vida, muerta a la que le cortaron "teta a teta la existencia" (71), cuerpo femenino que es destruido y se autodestruye, que se agrede y se asume. Ramos Otero dice "La patria soy yo", pero, como Julia de Burgos, ${ }^{41}$ uno de sus más reiterados modelos, asume la imagen femenina de la patria y de su propio cuerpo como imposición, como camino que es necesario desbrozar, como construcción que es preciso destruir y dispersar antes de postular lo que quedaría fuera del texto: el cuerpo nuevo de la patria y del yo.

${ }^{40}$ Ver dos de los poemas puertorriqueños de formación nacional más importantes y más conocidos (por tanto, más influyentes), "Puerto Rico" de José Gautier Benitez y “Alabanza en la torre de Ciales" de Juan Antonio Corretjer, Dia antes (Río Piedras: Antillana, 1973) 72-96.

${ }^{41}$ Véase "Poema para mi muerte", Yo misma fui mi ruta, 148. 
